\title{
Phosphatidylinositol 3,4,5-Trisphosphate 3-Phosphatase and Dual-Specificity Protein Phosphatase PTEN
}

National Cancer Institute

\section{Source}

National Cancer Institute. Phosphatidylinositol3,4,5-Trisphosphate 3-Phosphatase and

Dual-Specificity Protein Phosphatase PTEN. NCI Thesaurus. Code C18181.

Phosphatidylinositol 3,4,5-trisphosphate 3-phosphatase and dual-specificity protein phosphatase PTEN (403 aa, $47 \mathrm{kDa}$ ) is encoded by the human PTEN gene. This protein plays a role in signaling and as both a dual-specificity phosphoprotein phosphatase and a lipid phosphatase. 